\title{
Knowledge and attitudes in dementia held by general practitioners in the primary care setting of Botucatu, São Paulo, Brazil
}

\author{
Conhecimentos e atitudes em demência por parte de clínicos gerais \\ do setor de atendimento primário de Botucatu, São Paulo, Brasil \\ Vânia Ferreira de Sá MAYORAL'1, Paulo José Fortes VILLAS BOAS ${ }^{1}$, Alessandro Ferrari JACINTO2,3
}

\begin{abstract}
Background: Alzheimer's disease (AD) is the leading cause of dementia worldwide. Despite alarming evidence on dementia prevalence, the condition is still underdiagnosed by general practitioners (GPs) in primary care. Early detection of the disease is beneficial for patients and relatives, who should be provided comprehensive guidance on dealing with dementia complications, covering medical, family and social aspects, thereby providing an opportunity to plan for the future. Objective: The objective of this study was to assess the knowledge of and attitudes toward dementia held by GPs from a city in the interior of São Paulo State, Brazil. Methods: A non-randomized intervention study was conducted involving six lectures about dementia. Before and after the intervention, the participating physicians completed two quizzes about knowledge of and attitudes towards dementia. The study was carried out in the primary care services of the town and a total of 34 GPs participated in the study. Results: The mean age of the sample was $33.9( \pm 10.2)$ years and the majority (76.5\%) of the sample had not undertaken medical residency training. The mean number of correct answers on the Knowledge Quiz about dementia before and after the training intervention was 59.6 and 71.2\% ( $p<0.001)$, respectively. The comparison of the mean responses on the Attitude Quiz revealed no statistically significant difference between the two applications of the instrument, before and after intervention ( $p=0.059$ ). Conclusions: More training for GPs on dementia should be provided.
\end{abstract}

Keywords: Aged; General Practitioners; Knowledge; Attitudes; Dementia.

\section{RESUMO}

Introdução: A doença de Alzheimer é a principal causa de demência em todo o mundo. Apesar das evidências alarmantes sobre a prevalência de demência, a condição ainda é subdiagnosticada por clínicos gerais na atenção primária. A detecção precoce da doença é benéfica para pacientes e familiares, que devem receber orientações abrangentes sobre como lidar com as complicações relacionadas às demências, abrangendo aspectos médicos, familiares e sociais, proporcionando assim uma oportunidade de planejar o futuro. Objetivo: 0 objetivo deste estudo foi avaliar os conhecimentos e as atitudes em relação à demência por parte de clínicos gerais de uma cidade do interior de São Paulo, Brasil. Métodos: Foi realizado um estudo de intervenção não randomizado, envolvendo seis palestras sobre demência. Antes e depois da intervenção, os médicos participantes completaram dois questionários sobre conhecimentos e atitudes em relação à demência. 0 estudo foi realizado nos serviços de atenção primária da cidade e um total de 34 clínicos gerais participaram do estudo. Resultados: A idade média da amostra foi de 33,9 $( \pm 10,2)$ anos e a maioria $(76,5 \%)$ da amostra não havia realizado treinamento em residência médica. 0 número médio de respostas corretas no Questionário do Conhecimento sobre demência antes e após a intervenção de treinamento foi de 59,6 e 71,2\% $(p<0,001)$, respectivamente. A comparação das respostas médias no questionário de atitudes não revelou diferença estatisticamente significativa entre as duas aplicações do instrumento, antes e após a intervenção ( $p=0,059)$. Conclusões: Deve ser fornecido mais treinamento sobre demência para os clínicos gerais.

Palavras-chave: Idoso; Clínicos Gerais; Conhecimento; Atitude; Demência.

\footnotetext{
¿Universidade Estadual Paulista “Júlio de Mesquita Filho", Faculdade de Medicina de Botucatu, Departamento de Clínica Médica, Botucatu SP, Brazil. ¿Universidade Federal de São Paulo, Escola Paulista de Medicina, Departamento de Medicina, Disciplina de Geriatria e Gerontologia, São Paulo SP, Brazil. ${ }^{3}$ Universidade Federal de São Paulo, Escola Paulista de Medicina, Departamento de Medicina Preventiva, Ambulatório de Medicina Geral e Familiar, São Paulo SP, Brazil.

Vânia Ferreira de Sá MAYORAL (D) https://orcid.org/0000-0002-9228-6338; Paulo José Fortes VILLAS BOAS (iD) https://orcid.org/0000-0001-9876-3222; Alessandro Ferrari JACINTO (iD https://orcid.org/0000-0002-1977-5880

Correspondence: Alessandro Ferrari Jacinto; E-mail:alessandrojacinto@uol.com.br

Conflict of interest: There is no conflict of interest to declare.

Authors' contribution: VFSM: designed the study, collected and analyzed data and wrote the manuscript. PJFVB: revised the study. AFJ: designed the study, analyzed data and wrote the paper.

Received on February 18, 2020; Received in its final form May 18, 2020; Accepted on June 8, 2020.
} 


\section{INTRODUCTION}

The aging of the population has led to a substantial rise in the number of older people with cognitive decline and dementia. By 2050, there will be an estimated 152 million persons with dementia globally ${ }^{1}$. Every year, another 10 million people will develop dementia, of which 6 million are from low- to middle-income countries, such as Brazil ${ }^{1,2}$. The estimated global cost of the condition in 2015 was 818 billion USD, a figure set to rise to 2 trillion USD by $2030^{3,4}$.

Dementia is a syndrome whose main risk factor is age. In most cases, the disease is progressive and marked by cognitive decline, which impacts the individual's independence and autonomy ${ }^{5}$. Alzheimer's disease $(\mathrm{AD})$ accounts for $50-70 \%$ of all dementia cases ${ }^{6}$. Although $\mathrm{AD}$ dementia is a clinical condition with major personal, family and social impacts and no curative treatment, early detection is believed important because diagnosis allows patients and their carers to discuss future care plans, helping to reduce psychic distress and costs ${ }^{7,8,9,10}$.

In many countries, including Brazil, general practitioners (GPs) play a central role in the health of older people and especially in detecting individuals with dementia. However, the literature shows that dementia is underdiagnosed in primary care, delaying diagnosis and leading to unfavourable outcomes for patients and their relatives ${ }^{11,12,13}$. A systematic review showed that the main barrier to GPs establishing a diagnosis is lack of training and education on dementia. Moreover, lack of training leads to doubts and limited confidence among clinicians in confirming a dementia diagnosis and managing symptoms ${ }^{14}$. Other studies have shown that unclear guidelines on screening for cognitive decline, misunderstandings regarding drug therapy, and difficulties talking with patients and their relatives about the disease and its complications, can preclude early diagnosis of dementia in primary care $\mathrm{e}^{15,16,17}$.

Since 1988, following the creation of the Brazilian National Health System (SUS), primary care has become the main entry point to the public health system. Currently, $73 \%$ of older people are treated solely by the SUS and most of them receive care provided by GPs ${ }^{18,19}$. Studies on dementia detection involving medical students and physicians on the first year of medical residency programs in Brazil have shown the need to provide more in-depth education and training in the detection and diagnosis of cognitive impairments in older people ${ }^{20,21,22}$. This lack of training may be due to the teaching method used by medical schools, which until recently, focused on training students about serious illnesses involving hospital inpatients, with little emphasis on outpatient treatment, i.e., primary care. However, recent curriculum models now engage students in primary care practice. Nevertheless, studies point to the need for continuous teaching and training of newly graduated physicians in the practice of medicine, given the rapid demographic and epidemiological shifts that have taken place in the last few years. This limited professional training in internal medicine has prompted the present study assessing the knowledge and attitudes in dementia held by GPs from a primary care service of a city in the interior of São Paulo State, Brazil.

\section{METHODS}

\section{Study design and setting}

A quasi-experimental intervention study was conducted involving six lectures (60 minutes each) about dementia and/ or a presentation script. The lectures were delivered, and the scripts were written by a geriatrician with experience in dementia (VFSM). The lectures/presentation script covered the definition, epidemiology, diagnosis and management of dementia syndromes. Before and after the intervention, the participating physicians completed two quizzes about knowledge of and attitudes towards dementia ${ }^{18}$. The coordination of the health system of Botucatu held monthly meetings from $2 \mathrm{pm}$ to $5 \mathrm{pm}$ with GPs from the primary care service to deliver updates on health topics to these professionals. The primary care service of the city of Botucatu comprises 4 basic health units (UBS), 2 health centres (CS), 2 polyclinics and 12 family health units (USF). All 40 GPs of the city of Botucatu primary health service were invited to take part in the study, most of whom were newly graduated physicians.

\section{Data collection}

Data collection took place between August 2016 and January 2017, gathering sociodemographic data (name, age, gender), responses to questions about time since graduation from medical school, completion of medical residency and specialty, and also about previous training in dementia during medical school: ("How long have you been a practicing physician?", "Did you have any classes on dementia during your medicine course?", "Have you done a Medical Residency program?"; If so, in which specialty?", "Would you like to have refresher courses on dementia?").

\section{Participants}

All GPs of the primary health service of Botucatu $(n=40)$ commenced the study. Six physicians were excluded because they began classes but failed to complete the content and thus did not take part in the $2^{\text {nd }}$ application of instruments. Physicians wishing to take part in the study, but who could not be away from their posts at health units, were provided with a script containing the topics presented in the lectures. After completing the 2 quizzes in the presence of the researcher, 10 physicians received the intervention based on this script. Thirty days later, the same group completed the quizzes a second time.

\section{Instruments}

The instrument Knowledge and Attitudes Quiz about Dementia was developed in the United Kingdom in 2004 
with the purpose of measuring GPs' knowledge of, confidence with and attitudes to the diagnosis and management of dementia in primary care $^{16}$. In 2015, these instruments were translated and culturally adapted for use in the Brazilian setting ${ }^{20}$.The Knowledge Quiz contains 14 multiple-choice questions, each with five possible answers, only one of which is correct, with all questions including the response option "I don't know". The instrument is divided into 3 sub-items addressing aspects of dementia related to epidemiology (3 questions), diagnosis (8 questions) and management (3 questions).

The Attitude Quiz contains 10 sentences about physicians' thoughts on the management of patients with dementia, scored on a Likert-type scale with the following possible answers: "strongly agree", "agree", "neither agree nor disagree", "disagree" and "strongly disagree"16. The first five sentences relate to positive attitudes: "1. Much can be done to improve the quality of life of carers of people with dementia. 2. Families would rather be told about their relative's dementia as soon as possible. 3. Much can be done to improve the quality of life of people with dementia. 4. Providing diagnosis is usually more helpful than harmful. 5. Dementia is best diagnosed by specialist services", whereas the other sentences relate to negative attitudes: "6. Patients with dementia can be a drain on resources with little positive outcome. 7. It is better to talk to the patient in euphemistic terms. 8. Managing dementia is more often frustrating than rewarding. 9. There is little point in referring families to services as they do not want to use them.10. The primary care team has a very limited role to play in the care of people with dementia"16.

\section{Statistical analysis}

The data were analysed using the IBM-SPSS 21 statistical software. Numerical variables were expressed as mean and standard deviation, while categorical variables were expressed as frequency and percentage. Student's $t$-test was used to compare means. The level of significance adopted was 0.05 .

\section{Ethics committee}

This study and the free and informed consent form were analysed and approved by the Research Ethics Committee of the Clinical Hospital of the Botucatu School of Medicine-UNESP.

\section{RESULTS}

The mean age of the sample was $33.9( \pm 10.2)$ years, where the majority ( 18 subjects $-52.9 \%$ ) were $20-30$ years old. Race consisted of thirty-two self-declared white, one black and one yellow. Sixteen (47\%) of the physicians were female and $21(61.8 \%)$ had been practicing for up to 5 years. Six (17.6\%) physicians aged $47-59$ years had been practicing for 18 years or longer. Of the $8(23.5 \%)$ GPs who had undertaken medical residency training in the overall sample, 5 were $>47$ years old, 1 was aged 28 years and 2 aged $37-39$ years. The majority of the sample had not undertaken medical residency training $(76.5 \%)$. With regard to the question on having received classes on dementia during medical training, 29 (85.3\%) stated "yes". Of the participants who reported "no", 3 had been practicing for 1-5 years and 1 for 18 years. All of the physicians (100\%) stated that they wished to have a refresher course on dementia.

\section{Knowledge about dementia}

The Knowledge Quiz about dementia with response options and number of correct answers, before and after the training intervention of presentation class and/or script is given in Table 1. The mean number of correct answers before

Table 1. Knowledge Quiz about Dementia with response options and number of correct answers, before and after training intervention, of general practitioners from the primary care system of Botucatu city, São Paulo state.

\begin{tabular}{|c|c|c|c|c|}
\hline & Questions & Response options & Before & After \\
\hline \multirow{3}{*}{ Epidemiology } & $\begin{array}{l}\text { A general practitioner with a list } \\
\text { of } 1,000 \text { people aged } 60 \text { years } \\
\text { or older can expect to have the } \\
\text { following number of people with } \\
\text { dementia on the list }\end{array}$ & $\begin{array}{l}\text { A. } 10 \\
\text { B. } 500 \\
\text { C. } 200 \\
\text { D.70 } \\
\text { E.I don't know }\end{array}$ & $\begin{array}{c}13 \\
(38 \%)\end{array}$ & $\begin{array}{c}13 \\
(38.0 \%)\end{array}$ \\
\hline & $\begin{array}{l}\text { From } 65 \text { years of age, the } \\
\text { prevalence of dementia is } \\
\text { expected to: }\end{array}$ & $\begin{array}{l}\text { A. Double every } 5 \text { years } \\
\text { B. Double every } 10 \text { years } \\
\text { C. Double every } 15 \text { years } \\
\text { D. Double every } 20 \text { years } \\
\text { E. I don't know }\end{array}$ & $\begin{array}{c}9 \\
(26.4 \%)\end{array}$ & $\begin{array}{c}21 \\
(61.8 \%)\end{array}$ \\
\hline & $\begin{array}{l}\text { One of the risk factors for the } \\
\text { development of Alzheimer's } \\
\text { disease is: }\end{array}$ & $\begin{array}{l}\text { A. Hardening of arteries } \\
\text { B. Age } \\
\text { C. Nutritional deficiencies } \\
\text { D. Exposure to aluminium } \\
\text { E. I don't know }\end{array}$ & $\begin{array}{c}25 \\
(73.5 \%)\end{array}$ & $\begin{array}{c}25 \\
(73.5 \%)\end{array}$ \\
\hline
\end{tabular}




\begin{tabular}{|c|c|c|c|c|}
\hline & Questions & Response options & Before & After \\
\hline \multirow{8}{*}{ Diagnosis } & $\begin{array}{l}\text { All of the following are potentially } \\
\text { treatable etiologies of dementia } \\
\text { except: }\end{array}$ & $\begin{array}{l}\text { A. Hypothyroidism } \\
\text { B. Normal pressure hydrocephalus } \\
\text { C. Creutzfeldt-Jacob disease } \\
\text { D. Vitamin B12 deficiency } \\
\text { E. I don't know }\end{array}$ & $\begin{array}{c}24 \\
(70.6 \%)\end{array}$ & $\begin{array}{c}26 \\
(76.5 \%)\end{array}$ \\
\hline & $\begin{array}{l}\text { A patient suspected of having } \\
\text { dementia should be evaluated as } \\
\text { soon as possible as: }\end{array}$ & $\begin{array}{l}\text { A. Prompt treatment of dementia may prevent worsening of } \\
\text { symptoms } \\
\text { B. Prompt treatment of dementia may reverse symptoms } \\
\text { C. It is important to rule out and treat reversible disorders } \\
\text { D. It is best to institutionalise a dementia patient early in } \\
\text { the course of the disease } \\
\text { E. I don't know }\end{array}$ & $\begin{array}{c}20 \\
(58.8 \%)\end{array}$ & $\begin{array}{c}27 \\
(79.4 \%)\end{array}$ \\
\hline & $\begin{array}{l}\text { Which of the following procedures } \\
\text { is required to definitively confirm } \\
\text { that symptoms are due to } \\
\text { dementia? }\end{array}$ & $\begin{array}{l}\text { A. Mini-Mental State Exam } \\
\text { B. Postmortem } \\
\text { C. CAT scan of the brain } \\
\text { D. Blood test } \\
\text { E. I don't know }\end{array}$ & $\begin{array}{c}7 \\
(20.6 \%)\end{array}$ & $\begin{array}{c}18 \\
(52.9 \%)\end{array}$ \\
\hline & $\begin{array}{l}\text { Which of the following is not } \\
\text { a necessary part of the initial } \\
\text { evaluation of a patient with } \\
\text { possible dementia? }\end{array}$ & $\begin{array}{l}\text { A. Thyroid function test } \\
\text { B. Serum electrolytes } \\
\text { C. Vitamin B and foliate levels } \\
\text { D. Protein electrophoresis } \\
\text { E.I don't know }\end{array}$ & $\begin{array}{c}29 \\
(85.3 \%)\end{array}$ & $\begin{array}{c}29 \\
(85.3 \%)\end{array}$ \\
\hline & $\begin{array}{l}\text { Which of the following sometimes } \\
\text { resembles dementia? }\end{array}$ & $\begin{array}{l}\text { A. Depression } \\
\text { B. Acute confusional state } \\
\text { C. Stroke } \\
\text { D. All of the above } \\
\text { E. I don't know }\end{array}$ & $\begin{array}{c}27 \\
(79.4 \%)\end{array}$ & $\begin{array}{c}26 \\
(76.5 \%)\end{array}$ \\
\hline & $\begin{array}{l}\text { When a patient develops a sudden } \\
\text { onset of confusion, disorientation, } \\
\text { and inability to sustain attention, } \\
\text { this presentation is most } \\
\text { consistent with the diagnosis of: }\end{array}$ & $\begin{array}{l}\text { A. Alzheimer's disease } \\
\text { B. Acute confusional state } \\
\text { C. Major depression } \\
\text { D. Vascular dementia } \\
\text { E. I don't know }\end{array}$ & $\begin{array}{c}27 \\
(79.4 \%)\end{array}$ & $\begin{array}{c}31 \\
(91.2 \%)\end{array}$ \\
\hline & $\begin{array}{l}\text { 10. Which of the following is nearly } \\
\text { always present in dementia? }\end{array}$ & $\begin{array}{l}\text { A. Loss of memory } \\
\text { B. Loss of memory and incontinence } \\
\text { C. Loss of memory, incontinence and hallucinations } \\
\text { D. None of the above } \\
\text { E. I don't know }\end{array}$ & $\begin{array}{c}28 \\
(82.3 \%)\end{array}$ & $\begin{array}{c}31 \\
91.2 \%)\end{array}$ \\
\hline & $\begin{array}{l}\text { 11. Which of the following clinical } \\
\text { findings best differentiates } \\
\text { vascular dementia from } \\
\text { Alzheimer's? }\end{array}$ & $\begin{array}{l}\text { A. Word-finding problems } \\
\text { B. Short-term ( } 2 \text {-minute span) visual memory loss } \\
\text { C. Stepwise disease course } \\
\text { D. Presence of depression } \\
\text { E. I don't know }\end{array}$ & $\begin{array}{c}23 \\
(64.7 \%)\end{array}$ & $\begin{array}{c}26 \\
(76.5 \%)\end{array}$ \\
\hline \multirow{3}{*}{ Management } & $\begin{array}{l}\text { 12. The effect of anti-dementia } \\
\text { drugs is to: }\end{array}$ & $\begin{array}{l}\text { A. Temporarily halt the disease in all cases } \\
\text { B. Temporarily halt the disease in some cases } \\
\text { C. Temporarily halt the disease in some cases but often } \\
\text { causing liver damage } \\
\text { D. Permanently halt the disease in some cases } \\
\text { E. I don't know }\end{array}$ & $\begin{array}{c}25 \\
(73.5 \%)\end{array}$ & $\begin{array}{c}29 \\
(85.3 \%)\end{array}$ \\
\hline & $\begin{array}{l}13 \text { Which statement is true } \\
\text { concerning the treatment of } \\
\text { dementia patients who are } \\
\text { depressed? }\end{array}$ & $\begin{array}{l}\text { A. It is usually useless to treat them for depression because } \\
\text { feelings of sadness and inadequacy are part of the disease } \\
\text { B. Treatments of depression may be effective in alleviating } \\
\text { depressive symptoms } \\
\text { C. Anti-depressant medication should not be prescribed } \\
\text { D. Proper medication may alleviate symptoms of depression } \\
\text { and prevent further intellectual decline } \\
\text { E. I don't know }\end{array}$ & $\begin{array}{c}13 \\
(38 \%)\end{array}$ & $\begin{array}{c}11 \\
(32.3 \%)\end{array}$ \\
\hline & $\begin{array}{l}\text { 14. What is the function of the } \\
\text { ABRAZ, the Brazilian association } \\
\text { that provides patients and carers } \\
\text { with information? }\end{array}$ & $\begin{array}{l}\text { A. Help people understand the disease and cope better } \\
\text { with the symptoms and treatment } \\
\text { B. Provide outpatient medical treatment } \\
\text { C. Recruit people with dementia for research studies } \\
\text { D. All of the above } \\
\text { E. I don't know }\end{array}$ & $\begin{array}{c}15 \\
(44 \%)\end{array}$ & $\begin{array}{c}22 \\
(64.7 \%)\end{array}$ \\
\hline
\end{tabular}


Table 2. Comparison of mean correct answers on Knowledge Quiz about Dementia, before and after training intervention, of general practitioners $(n=34)$ from primary care system of Botucatu, São Paulo.

\begin{tabular}{lccc}
\hline Sub-items & $\begin{array}{c}\text { Before } \\
\text { intervention } \\
\text { mean (SD) }\end{array}$ & $\begin{array}{c}\text { After } \\
\text { intervention } \\
\text { mean (SD) }\end{array}$ & p-value* \\
\hline Epidemiology & $1.41( \pm 0.85)$ & $1.74( \pm 0.82)$ & 0.07 \\
\hline Diagnosis & $5.44( \pm 1.80)$ & $6.32( \pm 1.55)$ & $<0.001$ \\
\hline Management & $1.53( \pm 0.92)$ & $1.85( \pm 0.70)$ & 0.09 \\
$\begin{array}{l}\text { Total correct } \\
\text { answers** }\end{array}$ & $8.35( \pm 0.74)$ & $9.97( \pm 2.11)$ & $<0.001$ \\
\hline
\end{tabular}

*Student's paired $t$-test; **out of 14.

Table 3. Comparison of mean answers on Attitude Quiz towards Dementia, before and after training intervention, of general practitioners $(n=34)$ from primary care system of Botucatu, São Paulo.

\begin{tabular}{lccc} 
Subscales & $\begin{array}{c}\text { Before training } \\
\text { intervention } \\
\text { mean (SD) }\end{array}$ & $\begin{array}{c}\text { After training } \\
\text { intervention } \\
\text { mean (SD) }\end{array}$ & $\mathrm{p}$-value* \\
\hline $\begin{array}{l}\text { Positive } \\
\text { attitude }\end{array}$ & $14.68( \pm 2.92)$ & $15.03( \pm 2.91)$ & $0.59 * \star$ \\
$\begin{array}{l}\text { Negative } \\
\text { attitude }\end{array}$ & $11.32( \pm 2.27)$ & $12.35( \pm 2.20)$ & $0.09^{\#}$ \\
\hline
\end{tabular}

*Student's paired t-test; **higher means: more positive attitudes; "higher means: less negative attitudes.

and after the training intervention was 8.35 (59.6\%) and 9.97 (71.2\%), respectively. The percentage of correct answers on the epidemiology, diagnosis and management subscales before intervention were 44.1, 68.3, and 50.9\% versus 57.7, 79.7, and $61.7 \%$ after intervention, respectively. Results on Student's paired $t$-test for comparisons of mean correct answers on the quizzes before and after the training showed a statistically significant difference only on the diagnosis subscale $(\mathrm{p}<0.001)$ (Table 2).

\section{Attitudes to dementia}

The comparison of the mean responses on the Attitude Quiz is presented in Table 3, revealing no statistically significant difference between the two applications of the instrument, before and after intervention ( $\mathrm{p}=0.059)$.

\section{DISCUSSION}

This study employed two quizzes assessing the knowledge and attitudes of physicians about dementia. The mean total correct answers on knowledge before and after the intervention was 8.35 (59.6\%) and $9.97(71.2 \%)$ out of 14 points, respectively. Turner et al. ${ }^{16}$, used the same instruments in a single application to 127 GPs who had volunteered to join a randomized clinical trial of educational interventions to improve the detection and management of dementia. The GPs scored $67 \%$ overall on the quiz about knowledge of dementia and 48,74 and $73 \%$ on the epidemiology, diagnosis and management subscales, respectively. In the present study, the GPs exhibited a lower performance, scoring 59.6 versus $67 \%$ by British GPs. Brazilian scores on the epidemiology, diagnosis and management subscales also proved to be lower, at 44.1,68.3 and 50.9\%, respectively. The most common mistakes in the UK study involved questions on epidemiology, whereas Brazilian GPs erred most on epidemiology and management of dementia. However, both groups of GPs performed best on questions about diagnosis in dementia.

A previous study by Jacinto et al. of 152 medical residents of a federal university hospital in São Paulo state applied the same two quizzes used in the present study ${ }^{21}$. The sample comprised $40.8 \%$ ( $n=61)$ residents in neurology, psychiatry, and geriatrics and internal medicine, and therefore probably had contact with older people with dementia during training. The remaining residents $(59.2 \%)$ specialized in surgery and clinical subspecialties. Around 59.7\% of residents embarking on their programs reported having received good training on cognitive impairments during medical school. Another study where 155 final-year medical students from two different universities participated, 92 (59.7\%) considered that they had good training in cognitive alterations during their undergraduate medical course and 67 (58.8\%) declared having only theoretical training ${ }^{22}$. However, this group of students scored an average of 6.9 (49.2\%) on the Knowledge Quiz, pointing to the need for continued education, given that the workforce in the public health system in Brazil, akin to the UK, comprises very young doctors dealing with the population of older people users seeking public health services ${ }^{23}$.

The study by Downs et al..$^{24}$, assessing the effectiveness of educational interventions in improving detection and management of dementia, concluded that GPs have difficulty detecting and managing dementia symptoms. Two interventions showed positive results: a decision-support system built into the electronic medical records and practice-based workshops. There were improvements in detection and confidence of GPs in the diagnosis and management of dementia. A similar result was seen in the present study, where primary care GPs showed improved performance, post-training, on the epidemiology diagnosis and management subscales. These results confirm that continued education may be effective for improving detection of cognitive impairment and dementia in older adults in primary care.

Several barriers, for both doctors and patients, to early diagnosis of dementia in primary care were outlined in the European Carers' Report 2018 25 : GPs believed forgetfulness was part of normal aging and so gave little importance in diagnosis; and also due to the fact that no curative treatment exists, regarding patients and/or relatives, delay in seeking help at 
the early stage of the disease is explained by fears of prejudice among friends, at work and also amongst health professionals $^{26}$, where clear information is lacking on all aspects of dementia for physicians and for individuals who are aging ${ }^{26,27}$.

Regarding attitudes towards dementia held by GPs, the present study showed that most of them agreed much can be done to improve the quality of life of people with dementia (82.3\%) and of their carers (97.1\%), but 50\% believed dementia is best diagnosed by a specialist. Similar results were found in the study by Turner et al. ${ }^{16}$. These findings are alarming because individuals are unable to get an appointment to see a specialist following the onset of symptoms because neither patient nor relatives took the cognitive and functional impairments seriously, believing them to be part of normal aging. Another important finding of the study was that $20.6 \%$ strongly agreed with the statement that treating individuals with dementia is frustrating.

In the study by Ahmad et al.,. ${ }^{28}$ assessing the attitudes, awareness and practice regarding early diagnosis of dementia of 1011 GPs, they found that older physicians were more confident diagnosing and advising about dementia. However, although these physicians believed early diagnosis of dementia was beneficial, they were more likely to feel that patients with dementia can be a drain on resources with little positive outcome. By contrast, younger physicians were more positive and felt that much can be done to improve the quality of life of patients with dementia ${ }^{27}$.

The World Alzheimer Report 2017-2025 warns of the global impact of $\mathrm{AD}$ dementia in the near future and emphasizes the urgent need for awareness of this problem by society, public authorities and healthcare professionals ${ }^{29}$.

Banerjee et al. ${ }^{30}$ showed that programs that encourage the individual with dementia to share their experiences with students result in the deepening of knowledge about the cognitive decline by the student, favouring a change in attitude to deal with the manifestations of dementia.

The study by Alzheimer's Disease International (ADI) "World Alzheimer Report 2019 - Attitudes to dementia"31 showed that in Brazil, there is still a huge stigma and negative attitudes towards people with dementia by health professionals and people in the community. The authors believe that changes in attitudes to eliminate stigma about dementia should have the direct participation of individuals with dementia. In addition, the inclusion of students in the health field from the beginning of graduation so that they share the early stages of the disease can be the path to ethical management in the management of dementia.

The limitations of this study included the convenience sample and small sample size, all derived from a single location in Sao Paulo State. Future research should explore whether the same findings can be replicated in a larger, representative sample of GPs in Brazil.

\section{ACKNOWLEDGEMENTS}

We thank the GPs who kindly agreed to participate in this study.

\section{References}

1. Bastos LFCS. OPAS/OMS Brasil - Demência: número de pessoas afetadas triplicará nos próximos 30 anos I OPAS/OMS. Pan American Health Organization / World Health Organization; 2017. Available from: https://www.paho.org/bra/index.php?option=com_content\& view $=$ article\&id $=5560$ :demencia-numero-de-pessoas-afetadastriplicara-nos-proximos-30-anos\&ltemid $=839$

2. Kalache A. Coping with the longevity revolution. Cien Saude Colet. 2014 Aug;19(8):3306. https://doi.org/10.1590/1413-81232014198.02362012

3. World Health Organization. Global strategy and action plan on ageing and health. Geneva:WHO; 2017. Available from: https://www.who.int/ ageing/GSAP-Summary-EN.pdf.

4. Moorhouse P. Care planning in dementia: tips for clinicians. Neurodegener Dis Manag. 2014 Feb;4(1):57-66. https://doi. org/10.2217/nmt.13.76

5. Haaksma ML, Vilela LR, Marengoni A, Calderón-Larrañaga A, Leoutsakos J-MS, Olde Rikkert MGM, et al. Comorbidity and progression of late onset Alzheimer's disease: A systematic review. PLoS One. 2017 May;12(5):e0177044. https://doi.org/10.1371/ journal.pone. 0177044

6. Alzheimer's Disease International - The global voice on dementia. ADI-Strategic-Plan-2016-2019.pdf. 2017. Available from: https://www.alz.co.uk/sites/default/files/pdfs/ADI-StrategicPlan-2016-2019.pdf

7. Schulz R, O'Brien AT, Bookwala J, Fleissner K. Psychiatric and physical morbidity effects of dementia caregiving: prevalence, correlates, and causes. Gerontologist. 1995 Dec;35(6):771-91. https://doi.org/10.1093/geront/35.6.771

8. Briggs R. Comment. Primary Care and Dementia. Available from: https://books.google.com/books/about/Primary_Care_and_ Dementia.html?hl=pt-BR\&id =xz8pDgAAQBAJ

9. Mittelman MS, Ferris SH, Shulman E, Steinberg G, Levin B. A family intervention to delay nursing home placement of patients with Alzheimer disease. A randomized controlled trial. JAMA. 1996 Dec;276(21):1725-31. https://doi.org/10.1001/ jama.1996.03540210033030

10. Prince MJ. World Alzheimer Report 2016 - Improving healthcare for people living with dementia: Coverage, quality and costs now and in the future. 2016. Available from: https://www.alz.co.uk/research/ world-report-2016

11. Robinson AL, Emden CG, Elder JA, Lea EJ, Vickers JC, Turner PA. Multiple views reveal the complexity of dementia diagnosis. Australas J Ageing. 2008 Dec;27(4):183-8. https://doi.org/10.1111/ j.1741-6612.2008.00316.x

12. Nakamura AE, Opaleye D, Tani G, Ferri CP. Dementia underdiagnosis in Brazil. Lancet. 2015 Jan;385(9966):418-9. https://doi.org/10.1016/ S0140-6736(15)60153-2

13. Jacinto AF, Brucki S, Porto CS, Martins MA, Nitrini R. Detection of cognitive impairment in the elderly by general internists in Brazil. Clinics. 2011;66(8):1379-84. https://doi.org/10.1590/S180759322011000800012 
14. Koch T, Iliffe S, EVIDEM-ED project. Rapid appraisal of barriers to the diagnosis and management of patients with dementia in primary care: a systematic review. BMC Fam Pract. 2010 Jul;11:52. https:// doi.org/10.1186/1471-2296-11-52

15. Pentzek M, Vollmar HC, Wilm S, Leve V. Putting dementia awareness into general practice: The CADIF approach. Z Gerontol Geriatr. 2017 May;50(Suppl 2):44-7. https://doi.org/10.1007/s00391-017-1206-6

16. Turner S, Iliffe S, Downs M, Wilcock J, Bryans M, Levin E, et al. General practitioners' knowledge, confidence and attitudes in the diagnosis and management of dementia. Age Ageing. 2004 Sep;33(5):461-7. https://doi.org/10.1093/ageing/afh140

17. Poreddi V, Carpenter BD, Gandhi S, Chandra R, Bada Math SGS. Knowledge and attitudes of undergraduate nursing students toward dementia: An Indian perspective. Invest Educ Enferm. 2015 Dec;33(3):519-28. https://doi.org/10.17533/udea.iee.v33n3a16

18. Ministério da Saúde. Diretrizes Estratégicas. Diretrizes Estratégicas; 2015. Available from: http://bvsms.saude.gov.br/bvs/pacsaude/ diretrizes.php

19. Lindgren $\mathrm{H}$. Limitations in physicians' knowledge when assessing dementia diseases - an evaluation study of a decision-support system. Stud Health Technol Inform. 2011;169:120-4. https://doi. org/10.3233/978-1-60750-806-9-120

20. Jacinto AF, Oliveira EC, Citero VA. Brazilian transcultural adaptation of an instrument on physician's knowledge and attitudes towards dementia. Dement Neuropsychol. 2015 Jul-Sep;9(3):245-50. https:// doi.org/10.1590/1980-57642015DN93000006

21. Jacinto AF, Brucki SMD, Porto CS, Martins MA, Nitrini R. Screening of cognitive impairment by general internists using two simple instruments. Dement Neuropsychol. Jan-Mar 2012;6(1):42-7. https:// doi.org/10.1590/S1980-57642012DN06010007

22. Jacinto AF, Boas PJFV, Mayoral VFS, Citero VA. Knowledge and attitudes towards dementia in a sample of medical residents from a university-hospital in São Paulo, Brazil. Dement Neuropsychol. Jan-Mar 2016;10(1):37-41. https://doi.org/10.1590/S198057642016 DN10100007
23. Jacinto AF, Citero VA, Lima Neto JL, Villas Boas PJF, Valle AP, Leite AGR. Knowledge and attitudes towards dementia among finalyear medical students in Brazil. Rev Assoc Med Bras (1992). 2017 Apr;63(4):366-70. https://doi.org/10.1590/1806-9282.63.04.366

24. Downs M, Turner S, Bryans M, Wilcock J, Keady J, Levin E, et al. Effectiveness of educational interventions in improving detection and management of dementia in primary care: cluster randomized controlled study. BMJ. 2006 Mar;332(7543):692-6. https://doi. org/10.1136/bmj.332.7543.692

25. Alzheimer Scotland. European Carers's Report 2018; 2018. Available from: https://www.alzscot.org/news_and_community/news/4165_ european_carers_report_2018

26. Anderson D. Forget Me Not. Mental health services for older people: by the audit commission. Psychiatr Bull. 2001;25(5):198-9. https:// doi.org/10.1192/pb.25.5.198-a

27. Renshaw J, Scurfield P, Cloke L, Orrell M. General practitioners' views on the early diagnosis of dementia. Br J Gen Pract. 2001 Jan;51(462):37-8.

28. Ahmad S, Orrell M, Iliffe S, Gracie A. GPs' attitudes, awareness, and practice regarding early diagnosis of dementia. Br J Gen Pract. 2010 Sep;60(578):e360-5. https://doi.org/10.3399/bjgp10X515386

29. World Health Organization. Global action plan on the public health response to dementia 2017-2025; 2017. Available from: http://www.who.int/mental_health/neurology/dementia/action_ plan_2017_2025/en/

30. Banerjee S, Farina N, Daley S, Grosvenor W, Hughes L, Hebditch $M$, et al. How do we enhance undergraduate healthcare education in dementia? A review of the role of innovative approaches and development of the Time for Dementia Programme. Int J Geriatr Psychiatry. 2017 Jan;32(1):68-75. https://doi.org/10.1002/ gps.4602

31. International AD. World Alzheimer Report 2019: Attitudestodementia. Alzheimer's Disease International; 2019. Available from: https://www. alz.co.uk/research/world-report-2019 